\title{
BIOGAS FROM CASSAVA PEELS WASTE
}

\author{
Felix Aibuedefe Aisien ${ }^{1, *}$ and Eki Tina Aisien ${ }^{2}$ \\ ${ }^{1}$ Department of Chemical Engineering, University of Benin, Benin City, Nigeria \\ 2 Department of Environmental Management and Toxicology, University of Benin, Benin City, Nigeria
}

Article Info:
Received:
13 July 2019
Revised:
30 January 2020
Accepted:
4 February 2020
Available online:
5 March 2020
Keywords:
Cassava peels
Methane
Biogas
Biofertilizer
Anaerobic digestion

Article Info:

Revised:

30 January 2020

Accepted

Available online:

5 March 2020

Keywords:

Cassava peels

Anaerobic digestion

\section{ABSTRACT}

The increasing growth of cassava agro-industries in Nigeria has led to the enormous generation of cassava peels waste. The feasibility of generating biogas and biofertilizer for both domestic and agricultural applications from cassava peels waste inoculated with cow dung was investigated. Fresh and stale cassava peels were used in the study. Three pretreatment chemicals such as sodium hydroxide $(\mathrm{NaOH})$, calcium hydroxide $\left(\mathrm{Ca}(\mathrm{OH})_{2}\right.$ and ammonium chloride $\left(\mathrm{NH}_{4} \mathrm{Cl}\right)$ buffer solutions were used in pretreating the cassava peels and cow dung slurry. Six batch anaerobic biodigesters of 10 -litre capacity each were used in this study for 40 days retention period. The $\mathrm{pH}$, temperature, and volumes of biogas and methane produced were monitored and recorded daily. The fertilizer qualities (total solids, volatile solids, \% phosphorus, \% nitrogen, etc.) of the digester slurry and the digester sludge after 40 days digestion were determined using official methods of analysis of Association of Official Analytical Chemists (AOAC). The results showed that the amount of biogas generated is $2540 \mathrm{~cm}^{3} /$ day. The stale cassava peels and cow dung slurry and the use of $\mathrm{NH}_{4} \mathrm{Cl}$ pretreatment chemical gave the best biogas production and methane yield of $104,961 \mathrm{~cm}^{3}$ and $62.3 \%$ respectively. The digester sludge from the anaerobic digestion of cassava peels and cow dung showed and demonstrated good biofertilizer qualities.

\section{INTRODUCTION}

The continuous increase in energy demands has been a serious problem resulting from increased population growth, urbanization, and industrialization worldwide. This problem is more pronounced in underdeveloped and developing countries where the social-economic situations are quite low. Lack of infrastructures for energy generation, transmission, and distribution, unavailability of nonrenewable energy sources such as fossil fuels, low technology for energy conversion from renewable energy sources such as biogas, and lack of funds for purchase of fossil fuels, infrastructural and technology developments in energy sectors have been implicated in the near energy crisis in most underdeveloped and developing countries (Aisien, et. al., 2010; Kwasi - Effah et. al., 2015). However, since energy can be obtained from renewable energy sources such as waste materials, the issue of poverty as it relates to the energy crisis in undeveloped and developing countries can be seriously reduced. The renewable energy source such as biogas production from anaerobic digestion of organic waste materials which can be sourced from municipal solid waste, agricultural waste, industrial waste, and household waste can provide enormous energy worldwide (Aisien et. al., 2007b; Igbum, et. al., 2019). Besides, biogas can be produced from food waste (Huiru, et al., 2019). Biogas is a cheap form of renewable energy that can meet to a large extent the energy demands of the rural populace globally. It is a colourless flammable gas produced via anaerobic digestion of organic waste materials. It is a smokeless, hygienic and more convenient fuel to use than other solids fuels (Buren, 1979). The increased emphasis on the use of renewable energy from biogas over the nonrenewable energy source of fossil fuels, will not only reduce energy demands from fossil fuels which is becoming very expensive and can lead to energy crisis but will as well address the problems of greenhouse gas emissions, global warming, environmental pollution/degradation and health hazard (COP 21, 2015; Igbum, et. al., 2019). Biogas is a renewable energy source that is produced by the biological degradation of organic matters in the absence of oxygen. The biogas from anaerobic digestion of organic matters is a gas that comprises of methane (50-72 vol.\%), carbon (IV) oxide (25-45 vol.\%), nitrogen (>2 vol.\%), hydrogen sulphide (>1 vol.\%), water (2-7 vol. $\%$ ) and oxygen (>2 vol. $\%$ ) (Mel, et. al., 2015). There are three main biochemical processes involved in biogas production. These are hydrolysis, acidogenesis/acetogenesis and methanogenesis (Igwe, 2014) as indicated below. 
$\left(\mathrm{C}_{6} \mathrm{H}_{10} \mathrm{O}_{5}\right) n+n \mathrm{H}_{2} \mathrm{O} \rightarrow n\left(\mathrm{C}_{6} \mathrm{H}_{12} \mathrm{O}_{6}\right)-$ Hydrolysis

$n\left(\mathrm{C}_{6} \mathrm{H}_{12} \mathrm{O}_{6}\right) \rightarrow n \mathrm{CH}_{3} \mathrm{COOH}$-Acetogenesis/Acidogenesis

$3 \mathrm{nCH}_{3} \mathrm{COOH} \rightarrow n \mathrm{nH}_{4}+\mathrm{CO}_{2}$ - Methanogenesis

Biogas energy has been successfully used for lighting, heating, cooking, power generation and fuel for vehicles. Besides, the sludge from anaerobic digestion of waste materials can serve as a biofertilizer for the improvement of soil fertility (Aisien et al., 2007).

Nigeria is the world's largest producer of cassava (Manihot esculenta Crantz), producing over 46 million tons of cassava per year (IITA -1). According to FAO (2001), about 250 to $300 \mathrm{~kg}$ of cassava peels is produced per tonne of fresh cassava root processed. Cassava peel accounts for 8-15 wt.\% of the total dry matter of the root. Cassava peels composition consists of 20-31 wt.\% hemicelluloses, $16-42$ wt.\% cellulose and 6-8 wt.\% lignin. Other than fiber, peels also contain 81.9 - 93.9 wt.\% organic matter and 4.1- 6.5 wt.\% crude protein (Kongkiattikajorn and Sornvorawea, 2011). Analysis of mineral content of cassava peel indicated the following mineral content: 48.7 wt.\% C; 1 wt. \% N; 1.1 wt.\% K; 1.6 wt.\% P; 0.16 wt.\% NO3; 0.15 wt.\% Na; 0.9 wt.\% Ca; 125 mg/kg Zn; 15 mg/kg Cu; 180 mg/kg Mn; 16.7 mg/ $\mathrm{kg} \mathrm{Pb} ; 48.7$ wt.\% C/N; and 52.6 wt.\% ash (Adelekan and Bamgboye, 2009).

The increase in population growth coupled with the low cost of living in Nigeria has led to a drastic increase in cassava utilization in garri, starch, fufu, lafu, and flour production. This has contributed to a tremendous increase in cassava peels waste generation. The other wastes from cassava processing in Nigeria include; cassava wastewater, sievates and offal (wastes from "foo-foo" production). International livestock research institute (ILRI), 2015 reported that approximately $98 \%$ of Nigeria's cassava peels annually are wasted due to constraints associated with drying and was concerned about its safe use, particularly the presence of hydrocyanide and mycotoxins-related food poisoning. The indiscriminate disposal of cassava peels in landfills/waste dump sites has led to serious environmental pollution. This waste degrades to produce noxious leachate that contaminates both surface and underground water sources and other products that cause air pollution. The effects of these pollution problems associated with the degradation of cassava peels in dumpsites include foul odor and sometimes poisonous and polluted air, which when inhaled by man or animals may result in infection and diseases that may take a long time to manifest. In the same vein, vegetation and soil around the cassava peels' dumpsites are rendered unproductive and devastated due to biological and chemical reactions taking place during the degradation of cassava peels. Cassava peels have been used as a feedstuff for various livestock. Besides, cassava peels have found applications in the production of reducing sugar, bioethanol, biogas and biofertilizer (Aisien et al., 2010; Anaeto, et al., 2013; Kongkiattikajorn and Sornvorawea, 2011 and Olanbiwoninu and Odunfa, 2012).

Many types of research have been carried out with cassava peels waste alone and cassava peels with other waste materials especially animal wastes for biogas production.
Adelekan and Bamgboye (2009) and Ofoefule and Uzodimma (2009) reported that biogas production and methane yield improved significantly when cassava peels were combined with different animal wastes. They also stated that the ratio of cassava peels to animals waste that is, carbon to nitrogen ratio was very important to ensure increased production of biogas and methane yield. Besides, Ezekoye and Ezekoye (2009), Ilaboya et al. (2010), Ilori, et al., (2007) and Adeyanju, (2008) reported that the blending of cassava peels with other plants waste. They found out that there is the need to apply some small quantity of animal wastes as inoculum in other to achieve an appreciable increase in biogas production and methane yield. Bayitse et. al., 2014 reported that cassava peels co - digested with manure produce biogas and biofertilizer by optimizing carbon to nitrogen ratio. Nkodi et. al., 2018 and Olaniyan, et. al., 2017 stated that the combination of cassava peels with animal waste yield a larger volume of biogas compare with cassava peels alone. Besides, Sawyeer et. al., 2017; Onuorah, et. al., 2016 and Ben and Michael, 2018 reported that the appropriate carbon to nitrogen ratio must be maintained. They stated that cassava peel to the animal waste ratio of 30: 20 is required for maximum biogas yield. Olawale et. al., 2017 reported that the addition of cow dung (animal manure) lowered the $\mathrm{C}: \mathrm{N}$ ratio of the cassava peels to value between 20: 1 and 30: 1, which make co-substrate ideal for anaerobic digestion. Many other researchers have appreciated the unique nature of cassava peels substrate in terms of high concentration of cyanide. They reported that for sufficient biogas production from cassava peels there must be an appropriate pretreatment method in place (Deepanraj et. al., 2014; Nkodi, et. al., 2016; Mel, et. al., 2015; Ben and Michael, 2018; Igbum, et. al., 2019; Onuorah, et. al., 2016, Shah, et. al., 2015; Gopinattan, et al., 2015). They employed various chemical pretreatment methods such as the use of alkalis $\left(\mathrm{NaOH}, \mathrm{KOH}, \mathrm{NaHCO}_{3}, \mathrm{Ca}(\mathrm{OH})_{2}\right)$ of different concentration in the maintenance of the slurry/ substrate $\mathrm{pH}$ for optimum biogas production. However, the application of a buffer solution was not considered, which we believed would resist more change in slurry $\mathrm{pH}$ when compare with alkalis solutions. Another gap identified from previous studies on cassava peels conversion to biogas was that investigation on stale cassava peels bio-digestion was neglected. It is the stale cassava peels that are abundant in most cassava peels dumpsites that usually constitute its associated environmental pollution and health hazard. Therefore, this study is designed to address these gaps. The application of an acid buffer solution will be investigated together with the alkaline solution as pretreatment chemicals. Besides, fresh and stale cassava peels will be studied. A comparison will be made and the conclusion drawn.

Therefore, the focus of this study is to investigate the production of biogas from cassava peels, as a potential alternative source of energy using cow dung as an inoculum. Besides, to determine whether the digested sludge from the anaerobic digestion can be used as a source of biofertilizer. As a result of the identified gaps in previous research works on cassava peels for biogas production, the objective of the research was to investigate the effect 
of the nature of cassava peels, (fresh and stale) and the applications of different pretreatment chemicals (alkaline and acid buffer solutions) on biogas production and methane yield.

\section{MATERIALS AND METHODS}

\subsection{Materials collection}

$15 \mathrm{~kg}$ each of fresh and stale cassava peels were collected with clean polythene bags from the Imuetinyan cassava processing mill and Orore Obazee cassava waste dump site in Benin city respectively. Cow dung (inoculum) were obtained from Egharevba slaughterhouse in Benin city. Anaerobic digesters designed and fabricated by Aisien et al, 2007 were collected from Chemical Engineering laboratory, University of Benin, Benin city.

\subsection{Experimental design}

Six (6) anaerobic digesters A, B, C, D, E, and F were used in the studies. $A, B$, and $C$ were used for biogas production while $D, E$ and $F$ were for methane production for $\mathrm{NaOH}, \mathrm{Ca}(\mathrm{OH})_{2}$ and $\mathrm{NH}_{4} \mathrm{Cl}$ buffer solution pretreatment chemicals respectively.

\subsection{Method}

A $3.6 \mathrm{~kg}$ fresh cassava peels were washed with clean tap water and the water was allowed to drain out for about $20 \mathrm{~min}$. The washed fresh cassava peels were then ground with an electrically powered grinding machine using 5 litres of deionized water to form a slurry. Then a $4 \mathrm{~g}$ cow dung was mixed with 1 litre of deionized water to produce a cow dung slurry, which will serve as inoculum. Both slurries were transferred to 10 -litre plastic bowl and thoroughly mixed. Then, a $6 \mathrm{~g} / \mathrm{l} \mathrm{NaOH}$ solution was used as a pretreatment chemical and this was furtherly used to mixed the cassava peels and cow dung slurries in the bowl until the $\mathrm{pH}$ was 6.8. 4 litres each of the chemically pretreated mixed fresh cassava peels and cow dung slurries at $\mathrm{pH} 6.8$ was charged immediately into two, 10-litre airtight anaerobic digesters $A$ and $D$. The set up connected to digester $A$ was simply a gas measuring cylinder to measure the volume of biogas produced daily by the displacement method. However, the digester $\mathrm{D}$ was designed to measure the volume of methane produced. Hence, the set up was connected via a $4 \mathrm{~g} / \mathrm{l} \mathrm{NaOH}$ solution container such that the released biogas, carbon (IV) oxide and other gases were made to pass through the container. In the process, carbon (IV) oxide and other gases except methane gas were absorbed. The resultant methane produced was daily monitored and measured by displacement method. Both anaerobic digestion processes were observed for 40 days. The temperature of the digesting slurry was daily monitored with a thermometer while that of the digester sludge was measured with a thermocouple. The $\mathrm{pH}$ of the digesting slurry was monitored with a Jowrey $3020 \mathrm{pH}$ meter. A similar procedure was used for the stale cassava peels, except that the observed initial preparation of the stale cassava peels. This involved soaking of stale cassava peels in distilled water for 4 hours before blending. The essence of investigating the fresh and stale cassava peels was that both contribute to the environmental pollution and health hazard associated with cassava peels waste management. As a matter of fact, in most cassava peels dumpsites, the population of the stale cassava peels far outweigh that the fresh cassava peels. The effects of different chemical pretreatment on cassava peel and cow dung slurry for biogas production was furtherly investigated using a similar procedure as that of $\mathrm{NaOH}$ above, but this time $10 \mathrm{~g} / \mathrm{l}$ and $10.85 \mathrm{~g} / \mathrm{l}$ for calcium hydroxide and ammonium chloride buffer respectively were used as the pretreatment chemicals. This is because of the high concentration of cyanide in the form of hydrogen cyanide $(\mathrm{HCN})$ in cassava peels, especially during the bio-digestion process.

The fertilizing properties (total solids, volatile solids, \% nitrogen, \% phosphorus, \% potassium, ammonium, and $\mathrm{pH}$ ) were carried out in triplicate using official methods of analysis, AOAC (1990) on both the digester slurry and digester sludge before and after the 40 days anaerobic digestion respectively. Two sets of plastic bowls $\mathrm{G}$ and $\mathrm{H}$ containing garden soils and at least seven maize plants were used for the growth study. The cassava and cow dung digested sludge (biofertilizer) was added to plastic bowl G only, while plastic bowl $\mathrm{H}$ served as the control without biofertilizer. The bowls were well watered and were kept on a place that daily exposed them to sunlight. The height of the maize plants in plastic bowl $\mathrm{G}$ and $\mathrm{H}$ was observed for 4 weeks.

\section{RESULTS AND DISCUSSION}

The effects of the nature of cassava peels were investigated by anaerobic digestion of fresh cassava peels and cow dung and stale cassava peels and cow dung. Figure 1 shows the variation of biogas production from fresh and stale cassava peels and cow dung. The results show that for both fresh and stale cassava peels and cow dung, the biogas production started after $24 \mathrm{hrs}$. However, it was observed that in the first 5 days of the anaerobic digestion, the volume of biogas produced from stale cassava peels was significantly higher than the volume of biogas produced from fresh cassava peels. The high rate of production of hydrocyanic acid at the earlier stage of anaerobic digestion of the fresh cassava peels was the possible reason for the reduced volume of biogas production. Smith et. al., (1985) reported that the presence of cyanogenic glucosides in cassava peels could induce excess acid production and the release of cyanide, which is highly toxic to methanogenic arches, hence reduces biogas production. This was however different in the case of stale cassava peels substrate where there is little or no hydrocyanic acid left because of its initial degradation period. During this biodegradation period, the hydrocyanic acid produced, usually evaporate into the environment in the waste dumpsite. This result compares favorably with that reported by Cuzin and Labat, (1992) and Bayitse, et. al., (2014). Also, there was a gradual increase in biogas production for both fresh and stale cassava peels and cow dung digestion from the 5th day to the 11th day. During this period, there was no substantial difference between the volume of biogas produced from fresh and stale cassava peels and 
cow dung. Besides, the 12th and 13th days experienced a drastic increase in biogas production from both fresh and stale cassava peels. The maximum biogas production was recorded on the 13th day. This is an indication of the absence of hydrocyanic acid from the fresh cassava peels after about 13th day digestion period. Between the 14th day and 23rd day of digestion, there was a drastic decrease in biogas production for both fresh and stale cassava peels. Beyond 23rd day, the volume of biogas produced gradually decreased to almost an insignificant volume for both fresh and stale cassava peels. This might have been as a result of depletion of nutrients in both cassava peels and cow dung and reduction of the population of methanogenic microorganisms in the digesting slurry (Nkodi, et. al., 2018). It can be concluded that the volume of biogas produced was in a fluctuating manner during 40 days anaerobic digestion. Besides, the result shows that the cumulative volume of biogas produced from fresh cassava and cow dung slurry and stale cassava peels and cow dung slurry are 95,592 $\mathrm{cm}^{3}$ and $104,961 \mathrm{~cm}^{3}$ respectively. Therefore, the rate of biogas production was $2520 \mathrm{~cm}^{3} /$ day and $2390 \mathrm{~cm}^{3} /$ day for stale and fresh cassava peels respectively. The methane yields were $62 \%$ and $63 \%$ for stale and fresh cassava peels respectively. This results compared favourably with that reported by Ukpai and Nnabuchi (2012); Sawyerr, et. al., (2017) and Olaniyan, et. al., (2017).

The variation of $\mathrm{pH}$ with retention time for fresh and stale cassava peels and cow dung digestion is represented in Figure 2. The $\mathrm{pH}$ values varied from 6.2 to 7.5 and 6.7 to 7.8 for fresh cassava peels and cow dung slurry and stale cassava peels and cow dung slurry respectively. Smith et. al., (2007) and Mel, et. al., (2015) reported that the $\mathrm{pH}$ range of between 6.5 and 7.5 was required for optimum biogas production. The $\mathrm{pH}$ values were fluctuating within the 40 days anaerobic digestion period. The high $\mathrm{pH}$ values were only experienced after periodic adjustment. Thereafter, the $\mathrm{pH}$ value continuously decreased with retention time. The fluctuating pattern of $\mathrm{pH}$ may be attributed to the biodegradation of compounds that are present in the cassava peels and cow dung slurry (Onuorah, et. al., 2016). The earlier decrease in $\mathrm{pH}$ value of the mixture (slurry) was probably due to the conversion of initial product to hydrolytic products such as glycerol, fatty acids, which includes acetic acids, propanoic acids and butyric acid and these acids depressed the $\mathrm{pH}$ values (Ozturk, et. al., 1991). McCarty and Smith, (1997) reported that the acid nature of the system will negatively affect the activity of methanogenic bacteria and may lead finally to their death. Also, it has been established by researchers that there is an almost direct relationship between $\mathrm{pH}$ and the volume of gas production in any anaerobic digestion system (Aisien et. al., 2007b and Ahmad et. al., 2003).

Figure 3 shows the variation of temperature with retention time for fresh and stale cassava peels and cow dung. The results show that the average temperature of the digesting slurry for both fresh cassava peels and cow dung and stale cassava peels and cow dung varied from $280 \mathrm{C}$ to $35 \mathrm{oC}$. This temperature range falls within the mesophilic temperature range which enabled the micro-organisms to attend a maximum performance for biogas production (Igwe, 2014), hence, favourable biogas production at this temperature range. However, the temperature values fluctuated within the 40 days retention time. The fluctuating pattern of temperature may be attributed to the energy generated during the biodegradation of compounds that are present in the cassava peels and cow dung slurry, and the fluctuating environmental temperature. It was observed that there was quite a direct relationship between biogas production, methane yield and temperature. The results reported by Aisien et. al., (2007), Ukpai and Nnabuchi (2012), Igbum, et. al., (2019) and Sawyerr, et. al., (2017) conform.

The effects of the different pretreatment chemicals such as alkaline $\left(\mathrm{NaOH}, \mathrm{Ca}(\mathrm{OH})_{2}\right)$ and buffer $\left(\mathrm{NH}_{4} \mathrm{Cl}\right)$ on the volume of biogas production for fresh and stale cassava peels and cow dung slurry is shown in Figure 4 . The pattern of the results was similar to that observed in Fig-

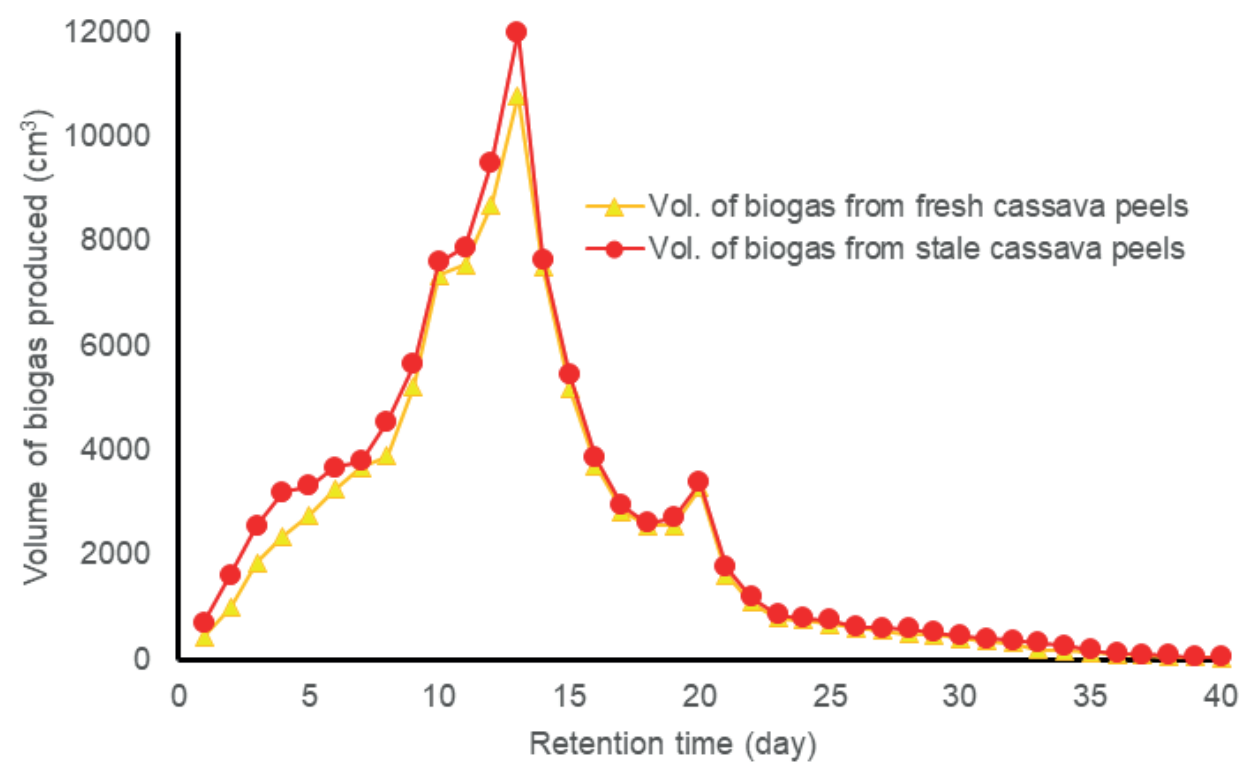

FIGURE 1: Variation of biogas produced with retention time from fresh and stale cassava peels and cow dung digestion. 


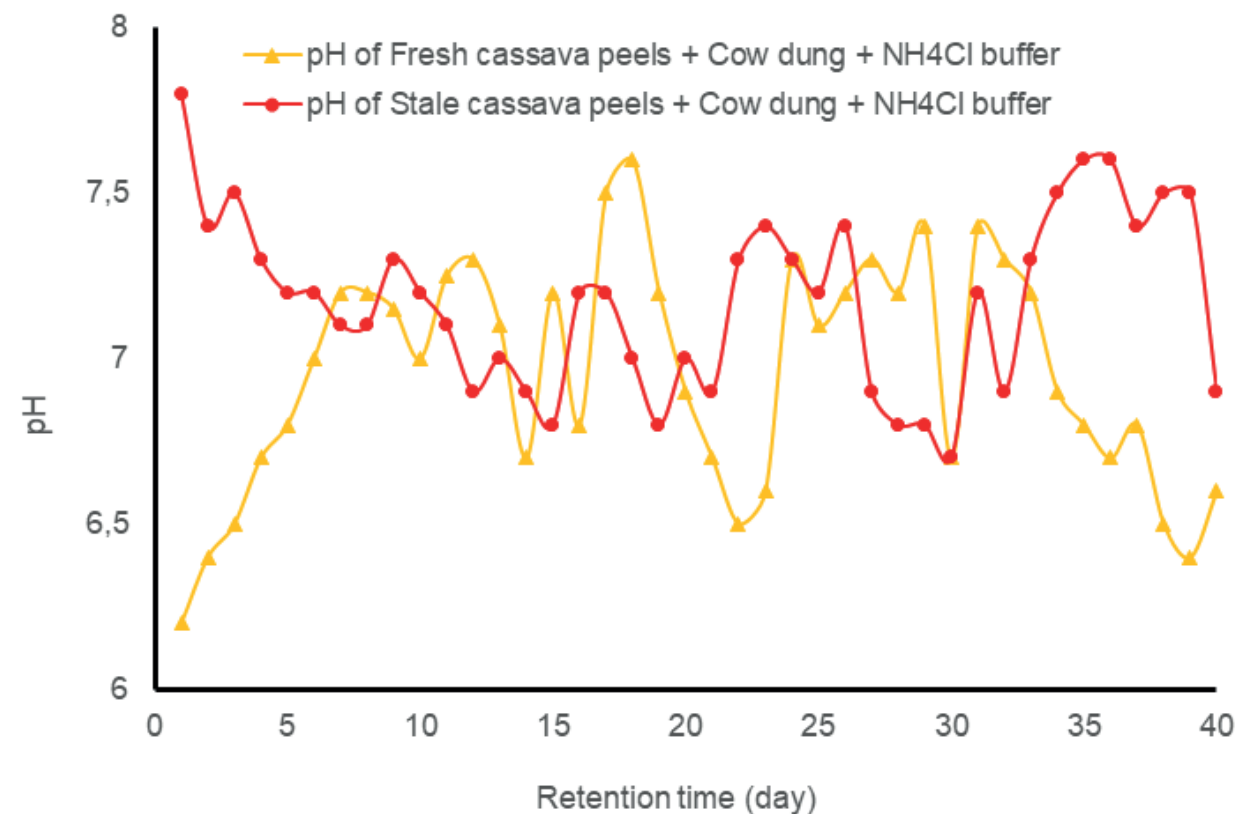

FIGURE 2: Variation of $\mathrm{pH}$ with retention time from fresh and stale cassava peels and cow dung digestion.

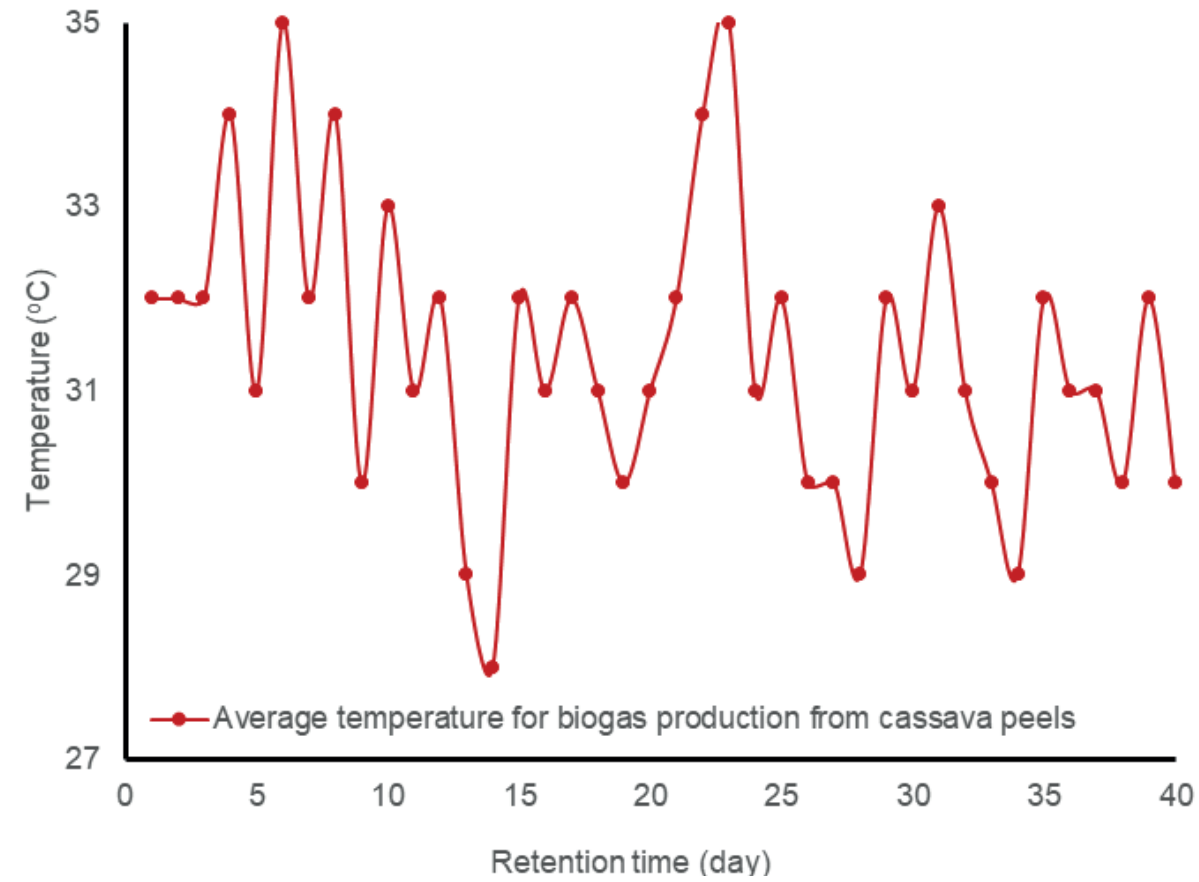

FIGURE 3: Variation of temperature with retention time for biogas production from fresh and stale cassava peels and cow dung.

ure 1. The use of $\mathrm{NaOH}$ pretreatment increased biogas production from cassava peels as reported by llaboya et al., (2010). Besides, Shah, et. al., (2015); Ben and Michael, (2018) and Gopinattan, et. al., 2015 reported that alkaline $\left(\mathrm{NaOH}\right.$ and $\mathrm{Ca}(\mathrm{OH})_{2}$ ) pretreatment methods generally enhanced biogas production from cassava peels. However, there was no substantial difference in the volume of biogas produced from both $\mathrm{NaOH}$ and $\mathrm{Ca}(\mathrm{OH})_{2}$, pretreatment chemicals as seen in Figure 4. This is an indication of the extent to which alkaline pretreatment chemicals can affect the change in biogas production. This might have been due to the erratic nature of cassava peels and cow dung slurry, which produced hydrocyanic acid in the early period of the anaerobic digestion (Cuzin and Labat 1992; Igwe, 2014). The $\mathrm{NH}_{4} \mathrm{Cl}$ buffer pretreatment chemical showed a substantial increase when compared with the alkaline pretreatment chemicals. This is an indication of the contribution of the buffer in the stabilization of the slurry $\mathrm{pH}$, being able to strongly resist the frequent change in $\mathrm{pH}$ resulting from the acidic nature of the slurry. Therefore, it is advisable to always apply buffer pretreatment chemicals rather than the alkaline pretreatment chemicals for a difficult substrate 


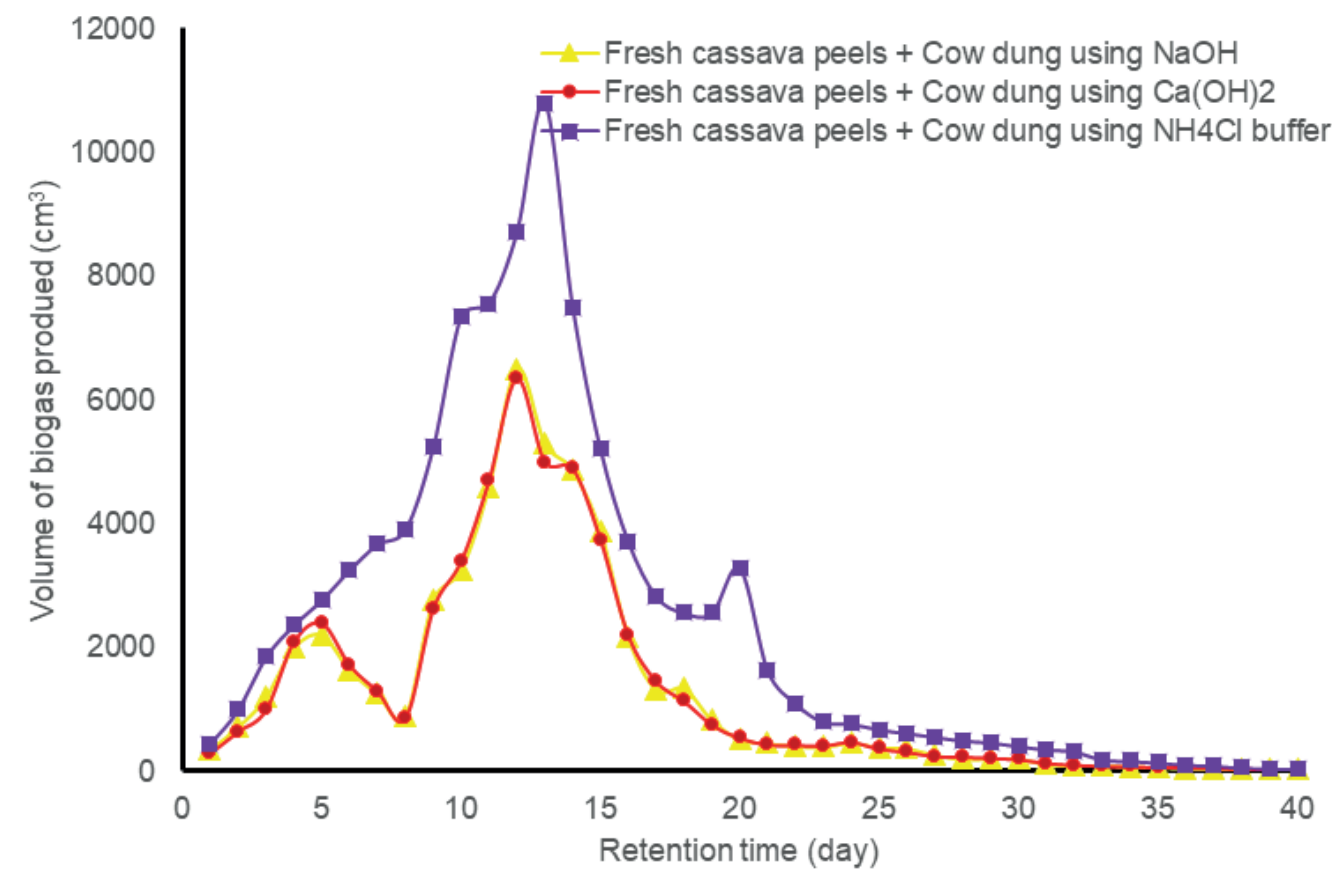

FIGURE 4: Variation of biogas produced with retention time using different pretreatment chemicals.

such as cassava peels to produce a substantially large volume of biogas and high yield of methane.

The cumulative volumes of biogas and methane, average $\mathrm{pH}$ and average temperature for the different chemical pretreatment methods for anaerobic digestion of fresh cassava peels and cow dung slurry are shown in Table 1. The cumulative volume of biogas and methane produced were $51,666 \mathrm{~cm}^{3}, 33,700 \mathrm{~cm}^{3} ; 51,29 \mathrm{~cm}^{3}, 32,310 \mathrm{~cm}^{3}$ and 95,592 $\mathrm{cm}^{3}, 58,890 \mathrm{~cm}^{3}$ for $\mathrm{NaOH}, \mathrm{Ca}(\mathrm{OH})_{2}$ and $\mathrm{NH}_{4} \mathrm{Cl}$ chemical pretreatment methods respectively. The methane yield for $\mathrm{NaOH}, \mathrm{Ca}(\mathrm{OH})_{2}$ and $\mathrm{NH}_{4} \mathrm{Cl}$ chemical pretreatment methods were $53.3 \%, 58.7 \%$ and $62 \%$ respectively. The average $\mathrm{pH}$ and average temperature were $6.71,32^{\circ} \mathrm{C} ; 6.69,31.4^{\circ} \mathrm{C}$; and $7.00,30.6^{\circ} \mathrm{C}$ for $\mathrm{NaOH}, \mathrm{Ca}(\mathrm{OH})_{2}$ and $\mathrm{NH}_{4} \mathrm{Cl}$ chemical pretreatment methods respectively. This shows that the acid buffer pretreatment method gave the most favourable results.

Figure 5 shows the $\mathrm{pH}$ variation patterns for the anaerobic digestion of fresh cassava peels and cow dung slurry using $\mathrm{NaOH}, \mathrm{Ca}(\mathrm{OH})_{2}$ and $\mathrm{NH}_{4} \mathrm{Cl}$ chemical pretreatment methods. The $\mathrm{pH}$ variation patterns using $\mathrm{NaOH}$ and $\mathrm{Ca}(\mathrm{OH})_{2}$ chemical pretreatment methods were quite similar. It was observed that the $\mathrm{pH}$ gradually increased to a particular level and then start decreasing to the lowest level until it was readjusted again to $\mathrm{pH} 6.8$ using $8 \mathrm{M} \mathrm{NaOH}$ and $\mathrm{Ca}(\mathrm{OH})_{2}$, solutions. This trend continues throughout the 40 days digestion period. However, the $\mathrm{NaOH}$ pretreatment method shows a slightly higher $\mathrm{pH}$ variation. The pattern for fresh cassava peels and cow dung using $\mathrm{NH}_{4} \mathrm{Cl}$ buffer pretreatment method was very different from that of $\mathrm{NaOH}$ and $\mathrm{Ca}(\mathrm{OH})_{2}$ pretreatment methods. As for the $\mathrm{NH}_{4} \mathrm{Cl}$ buffer pretreatment method, the fluctuation of the slurry $\mathrm{pH}$ was not much and was within the $\mathrm{pH}$ range for optimum biogas production, hence it was not necessary to readjust the $\mathrm{pH}$ for optimum biogas production as in the case of alkaline pretreatment methods. This might be as a result of the buffering effect of $\mathrm{NH}_{4} \mathrm{Cl}$ buffer before the commencement of the anaerobic digestion. Table 1 shows that the average $\mathrm{pH}$ of $6.71,6.69$ and 7.0 for $\mathrm{NaOH}, \mathrm{Ca}(\mathrm{OH})_{2}$ and $\mathrm{NH}_{4} \mathrm{Cl}$ chemical pretreatment methods respectively. This result compared favourably with that reported by Wantanee and Sureelak, (2004). They reported that most researches on biogas production using cassava materials and animal's waste (inoculums), neutralizers have been applied to the slurry to bring the $\mathrm{pH}$ of the slurry to neutrality. Buren (1983) reported that the micro-organisms involved in

TABLE 1: The cumulative volumes of biogas and methane, average $\mathrm{pH}$ and the average temperature of fresh cassava peels to cow dung with different pretreatment chemical methods.

\begin{tabular}{|c|c|c|c|c|}
\hline $\begin{array}{l}\text { Fresh cassava peels to cow dung with differ- } \\
\text { ent chemical pretreatment }\end{array}$ & $\begin{array}{l}\text { Cumulative volume of } \\
\text { biogas }\left(\mathrm{cm}^{3}\right)\end{array}$ & $\begin{array}{l}\text { Cumulative volume of } \\
\text { methane }\left(\mathrm{cm}^{3}\right)\end{array}$ & Average $\mathrm{pH}$ & Average temperature \\
\hline $\begin{array}{l}\text { Cassava peels and cow dung mixed slurries } \\
\text { using } \mathrm{NaOH} \text { pretreatment }\end{array}$ & 51,666 & 33,700 & 6.71 & 32.0 \\
\hline $\begin{array}{l}\text { Cassava peels and cow dung mixed slurries } \\
\text { using } \mathrm{Ca}(\mathrm{OH})_{2}\end{array}$ & 51,295 & 32,310 & 6.69 & 31.4 \\
\hline $\begin{array}{l}\text { Cassava peels and cow dung mixed slurries } \\
\text { using } \mathrm{NH}_{4} \mathrm{Cl}\end{array}$ & 95,592 & 58,890 & 7.00 & 30.6 \\
\hline
\end{tabular}




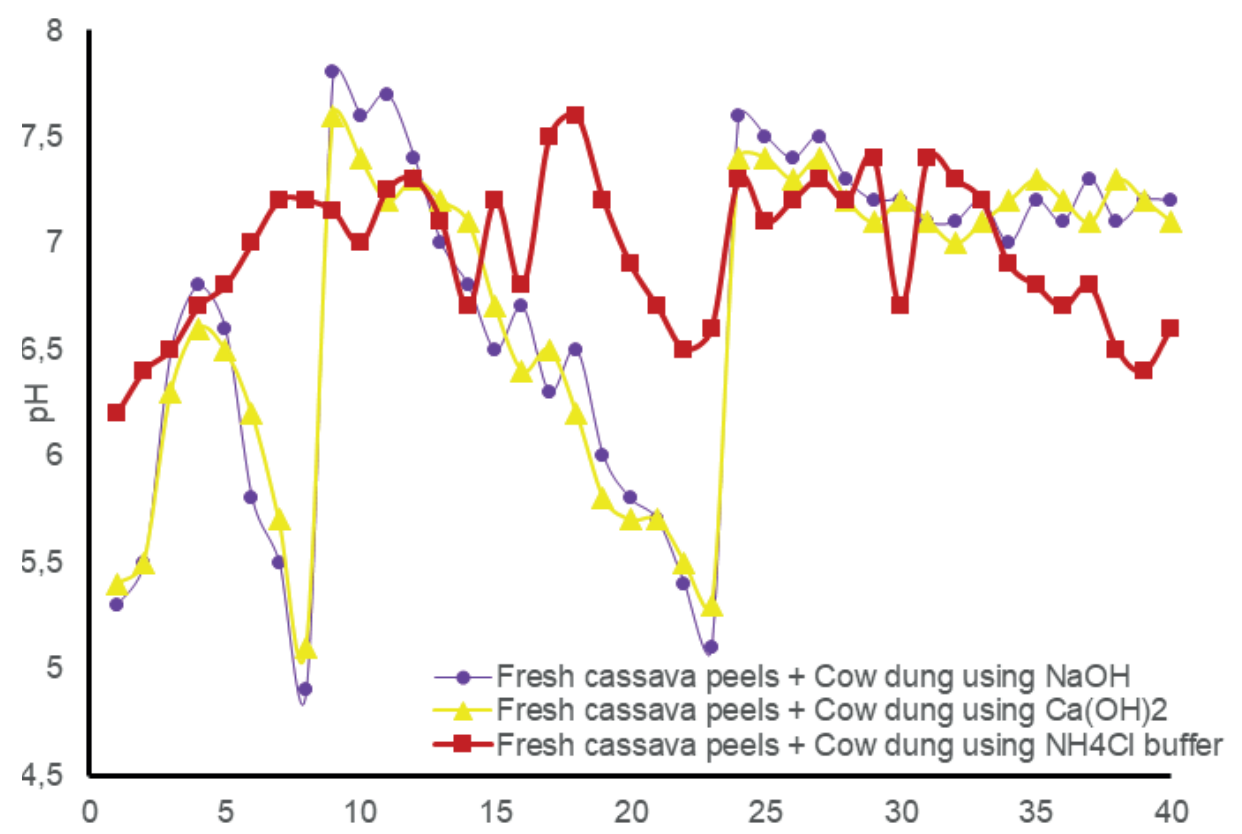

Retention time (day)

FIGURE 5: Variation of $\mathrm{pH}$ with retention time using different pretreatment chemicals.

anaerobic bio-digestion require a neutral or mildly alkaline environment, as a too-acidic or too-alkaline environment will be detrimental.

Table 2 shows the results of the chemical composition of cassava peels and cow dung slurry compared with cassava peels and cow dung digested sludge (biofertilizer) after 40 days anaerobic digestion. The fertilizer quality parameters (nitrogen, phosphorus and potassium) of the biofertilizer shows percentage increase of $75 \%, 79.35 \%$ and $50.77 \%$ for nitrogen, phosphorus and potassium respectively. However, there was $54.02 \%, 80.95 \%$ and $56.04 \%$ percent decrease in total solids, volatile acids and ammonia respectively. The $\mathrm{pH}$ of the digested sludge was within the limit for good biofertilizer. It has been reported that digested sludge can conserve fertilizer elements with a strong potential to recondition the soil and increase its fertility (Zhang, et al., 2013). Bayitse, et. al., (2014) reported that the sludge from cassava peels and manure is a good biofertilizer. The anaerobic digestion of cassava peels and cow dung slurry improved its value as fertilizer supplement because the available nitrogen and other substances increased in the produced sludge (Bayitse, et. al., 2014).
These results are a strong indication of a good quality biofertilizer from anaerobically digested sludge from cassava peels and cow dung. This was further confirmed when the biofertilizer was applied to soil used for maize plants cultivation. It was observed that the maize plants grown in the soil which contained the biofertilizer, grew much better than that from the soil without the biofertilizer. This result was similar to that earlier reported by Aisien et al., 2007 where the application of the digested sludge from cassava wastewater helped in improving plants growth. Also, Sawyerr et al., (2017) reported that anaerobic co-digestion of cassava peels and cow waste generate energy like biogas and at the same time, the digested sludge from it can be used as fertilizer for agricultural applications. The sensory evaluation test carried out on the digested sludge (biofertilizer) after 40 days anaerobic digestion of cassava peels and cow dung shows that the biofertilizer odour level was extremely unobjectionable and this was an indication of significant reduction of odour after 40 days anaerobic digestion.

The result in Table 2 is in Mean \pm SEM.

TABLE 2: The chemical composition of slurry and digested sludge from cassava peels and cow dung.

\begin{tabular}{|c|c|c|c|}
\hline Parameters & Input Slurry & Output Digested Sludge & Percentage increase or decrease \\
\hline Total Solids (\%) & $6.22 \pm 0.42$ & $2.86 \pm 0.3$ & 54.02 \\
\hline Volatile Acids (acetic acid mg/l) & $735 \pm 3.2$ & $140 \pm 2.2$ & 80.95 \\
\hline Nitrogen (\%) & $0.45 \pm 0.12$ & $0.78 \pm 0.2$ & 75.00 \\
\hline Phosphorus (\%) & $0.92 \pm 0.22$ & $1.65 \pm 0.27$ & 79.35 \\
\hline Potassium (g/l) & $6.46 \pm 0.54$ & $9.74 \pm 0.4$ & 50.77 \\
\hline Ammonia (g/l) & $0.72 \pm 0.15$ & $0.31 \pm 0.1$ & 56.94 \\
\hline $\mathrm{pH}$ & $5.8 \pm 0.2$ & $7.28 \pm 0.3$ & 2.52 \\
\hline
\end{tabular}




\section{CONCLUSIONS}

The following conclusions can be drawn from this study:

There were low biogas production/methane yield and slow onset of gas production at the beginning of the anaerobic digestion for the fresh cassava peels - cow dung mixed when compared with that of stale cassava peels - cow dung mixed.

The cumulative biogas production after 40 days anaerobic digestion of stale cassava peels - cow dung mixed and fresh cassava peels - cow dung mixed were $104,961 \mathrm{~cm}^{3}$ and $95,592 \mathrm{~cm}^{3}$ respectively.

There was no substantial increase in biogas production and methane yield for fresh cassava peels - cow dung mixed with $\mathrm{NaOH}$ and $\mathrm{Ca}(\mathrm{OH})_{2}$ alkaline pretreatment without occasional pH adjustment. However, there was a significant improvement in biogas production and methane yield with the use of $\mathrm{NH}_{4} \mathrm{Cl}$ buffer pretreatment without any $\mathrm{pH}$ adjustment.

- The $\mathrm{pH}$ range (6.5 - 7.5) and temperature range (28 $35^{\circ} \mathrm{C}$ ) during the 40 days anaerobic digestion period were within the acceptable range for optimum biogas production and methane yield of $104,961 \mathrm{~cm}^{3}$ and $62.3 \%$ respectively.

- The biofertilizer from the anaerobic digestion of cassava peels and cow dung sludge after 40 days digestion time was of good quality that improved the soil fertility and hence enhanced growth of the maize plants.

\section{REFERENCES}

Adelekan, B.A., Bamgboye, A.I. 2009. Comparison of biogas productivity of cassava peels mixed in selected ratios with major livestock waste types. African Journal of Agricultural Research.4 (7):571577.

Adeyanju, A. A. 2008. Effect of seeding of wood ash on biogas production using pig waste and cassava peels. Journal of Engineering and Applied Sciences, Vol. 3, No. 3, 242- 245,

Docsdrive. com/pdfs/medwelljournals/jeasci/2008/242- 245.pdf.

Ahmad, A.L., Ismail. S., Ibrahim, N., Bhatia, S. 2003. Removal of suspended solids and residual oil from palm oil mill effluent. J. Chem. Tech. and Biotech. 78 971-978.

Aisien, F.A., Akakasiaka, U.F., Otoibhi, O.G., Aisien, E.T. 2007. Design and fabrication of a prototype biogas digester In: Ibhadode A.O. (Eds.), Advances in Materials and Systems Technologies Trans TECH Publisher. Switzerland pp. $527-532$.

Aisien, F.A.; Odafin, C.A., Aisien, E.T. 2007b. Application of cassava wastewater sludge as a liquid fertilizer. Journal of Civil and Environmental Systems Engineering, vol. 8, No. 1, pp. 31 - 39.

Aisien, F.A., Aguye, M.D. and Aisien, E.T. 2010. Blending of ethanol from cassava wastewater with gasoline as a source of automobile fuel. Electronic Journal of Environmental, Agricultural and Food Chemistry, vol. 9,(8) pp. $445-450$.

Anaeto, M., Sawyerr, A.F., Alli, T.R., Tayo, G.O., Adeyeye, J.A. Olarinmoye, A.O. 2013.Cassava lead silage and cassava peel as dry season feed for West African dwarf sheep. Global Journal of Science Frontier Research Agriculture and Veterinary Sciences.13 (2).

AOAC 1990. Official Methods of Analysis of Assoc. of Analytical Chemistry, 14th edn, Arlinton, Virginia, 2209.

Arowolo, A.A. and Adaja, J.I. 2012. Investigation of Manihot Esculenta and Manihot Duleis production in Nigeria: An Econometric Approach. J. Appl. Sci. Environ. 3:18-24.

Bayitse, R.; Laryea, G.N.; Selormey, G.; Oduro, W.O.; Aggey, M.; Mansah, B.; Gustavsson, M. And Bjrre, A.B. 2014. Anaerobic co-digestion of cassava peels and manure: A technological approach for biogas generation and biofertilizer production - A feature article, Journal of applied science and technology (JAST), vol. 19: No. $1 \& 2$, pp. $10-17$.
Ben, M.G. and Michael, E.I. 2018. Biogas production from farm waste (cassava peels and swine dung): Co-digestion and prospect on economic growth. Res. Rev. J. Ecol., Environ. Sci., vol.6 issue 2, pp. $58-63$.

Buren, A.V. 1979. A Chinese biogas manual. intermediate technology publications Ltd, pp. 11-24.

Buren, V. 1983. A Chinese biogas manual. popularizing technology. Countryside intermediate technology Publications Ltd.

COP 21 2015. Adaptation and resilience to climate change. 21st Conference of Parties on Climate Change, 30 November. to 11 December, Paris, France.

Cuzin, N., Labat M. 1992. Reduction of cyanide levels during anaerobic digestion of cassava. Int. J. Food Sci.Technol. 27:329-336.

Deepanraj, B.; Sivasubramanian, V. and Jayaraj, S. 2014. Biogas generation through anaerobic digestion process research. A review Journal of Chemistry and Environment, 18 (5) pp. 80 - 93.

Ezekoye V.A., Ezekoye, B.A. 2009. Characterization and storage of biogas produced from the anaerobic digestion of cow dung, spent grains/cow dung, and Cassava peels/rice husk. Pac. J. Sci. Technol.10 (2):898-904.

FAO 2001. Proceedings of The validation forum on the global cassava development strategy. Food and Agriculture Organization of the United Nations International Fund for Agricultural Development Rome, 2001. p. 65

Gopinattan, C.; Himanshu, R. and Romilly, M.M. 2015. Cost-effective pretreatment of cassava peels for enhanced biogas production. IOSR Journal of Environmental Science, Toxicology and Food Technology, vol. 9, issue 9, pp. $21-25$.

Huiru, Z.; Yunjun, Y. ; Liberti, F.; Bartocci, P. and Fantozzi, F. 2019. Feasibility analysis of an anaerobic digestion plant fed with canteen food waste. Energy Conversion and Management, vol. 180, pp. $938-948$

Igbum, O.G.; Eloka-Eboka, A.C. and Adoga, S. 2019. Feasibility study of biogas energy generation from refuse dump in a community based distribution in Nigeria. International Journal of Low - Carbon Technologies, vol. 14, issue 2, pp. 58 - 78.

Igwe, N.J., 2014. Production of biogas from cassava and plantain peels blended with cow dung. International Journal of Life Sciences Biotechnology and Pharma Research, 3(4): 201-213

Ilaboya, I.R., Asekhame F.F., Ezugwu M.O., Erameh A.A., Omofuma, F.E. 2010. Studies on biogas generation from Agricultural Waste; Analysis of the effects of alkaline on gas generation. World Appl. Sci. J. 9(5):537- 545.

Ilori, M.O., Adebusoye, S.A., Lawal, A.K., Awotiwon, O. A. 2007. Production of biogas from banana and plantain peels. Advances Environmental Biology, Vol. 1, No. 1, 33-38, http://www.the free library.com/production +of biogas + from +banana + and +plantain+peels.-a0215720206

IITA -1 (http://www.iita.org/cassava, assessed 3/9/2013).

Kongkiattikajorn J., Sornvorawea B. 2011. Comparative study of bioethanol production from cassava peels by monoculture and co-culture of yeast. Kasetsart Journal (Natural. Science). 45:268-274.

Kwasi - Effah, C. C., Obanor, A. I., Aisien, F.A. 2015. A Technical approach to balance the use of renewable and non-renewable energy sources." American Journal of Renewable and Sustainable Energy $1,(3), 156-165$.

ILRI. 2015. Scaling the use of cassava peels as quality livestock feed in Africa. ILRI Research Proposal Summary. Nairobi, Kenya

McCarty, P. L, Smith, D 1987. Effect of hydrogen concentration on population distribution and kinetics in methanogenesis of Propionate Biotechnology Advance in Processing Municipal waste for Fuels and Chemicals. Antonopoulos New \& Jersey, Noyes Data CO. Ofoefule, A.U., Uzodinma E.O. 2009. Biogas production from blends of cassava (Manihot utilissima) peels with some animal wastes. Int. J. Phys. Sci. 4(7):398-402.

Nkodi, T.M.; Taba, K.M.; Kayembe, S.; Mulaji, C. and Mihigo, S. 2016. Biogas production by co-digestion of cassava peels with urea. IJSET (5) : 3, pp. $139-141$

Nkodi, T.M.; Kayembe, J.S.; Biey, M.E. and Taba, K.M. 2018. Comparative study of co-digestion of composted mixtures of cassava peels and coffee pulp with or without cow dung. International Journal of Engineering Research and General Science, vol. 6, issue 2, pp. $109-114$.

Mel, M.; Ihsan, S.I. and Setyobudi, R.H. 2015. Process improvement of biogas production from anaerobic co-digestion of cow dung and corn husk. Procedia Chemistry, 14. Pp. 91 - 100. 
Olanbiwoninu, A. A., Odunfa S.A. 2012. Enhancing the production of reducing sugars from cassava peels by pretreatment methods. International Journal of Science and Technology. 2(9):650-657.

Olaniyan, A.M.; Olawale, T.T.; Alabi, K.P.; Adeleke, A.E. and Oyeniyi, S.K. 2017. Design, construction and testing of a biogas reactor for production of biogas using cassava peel and cow dung as biomass. Arid Zone Journal of Engineering, Technology and Environment, vol. 13 (4) pp. $478-488$.

Olawale, O.E.; Oguntibeju, E.E. and Olawaseyi, J.B. 2017. Empirical analysis of energy potentials in co-substrates from cassava peels, cow dung and sawdust. Proceeding of the world congress on July $5-7$, London, U.K.

Onuorah, S.; Orji, M.I.; Okigbo, R. and Okeke, J. 2016. Co-digestion of livestock wastes for biogas production. Bioengineering and Bioscience 4 (3), pp. $42-49$.

Ozturk, M. 1991.Conversion of Acetate, Propionate and butyrate to methane under thermophilic condition in batch reactors" Water research 25(12):1509-1513.

Sawyerr, N. Trois, C., Workneh, T., Okudoh, V. 2017. Co-digestion for animal manure and cassava peels for biogas production in South Africa 9th International conference on advances in science, engineering, technology and waste management (ASETWM-17) Nov. 27-28, Parys, South Africa.
Shah, F.A.; Mahmood, Q.; Rashid, N.; Pervez, A.; Raja, I.A. and Shah, M.M. 2015. Co-digestion, pretreatment and digester design for enhanced methanogenesis. Renewable and Sustainable Energy Reviews, 42, pp. $627-642$.

Smith, M. R., Lequerica, J. L. Hart, M. R. 1985. Inhibition of methanogenesis and carbon metabolism in methanosarcina sp. by cyanide. J. Bactenol., 162, pp. 67-71.

Smith, K.; Cumby, T.; Lapworth, J.; Misselbrook, T. and Williams, A. 2007. Natural crusting of slurry storage as an abatement measure for ammonia emission on dairy farms. Biosys. Eng. 97, pp. $464-471$.

Ukpai, P. A Nnabuchi, M. N. 2012. Comparative study of biogas production from cow dung, cowpea and cassava peeling using 45 litres biogas digester Advances in Applied Science Research, 3 (3):1864-1869.

Wang, X., Yang G., Feng Y., Ren G., Han X. 2012. Optimizing feeding composition and carbon-nitrogen ratios for improved methane yield during anaerobic co-digestion of dairy, chicken manure and wheat straw. Bioresour. Technol. 120:78-83.

Wantanee, A., Sureelak R. 2004. Laboratory scale experiments for biogas production from cassava tubers. The Joint International Conference on "Sustainable Energy and Environment (SEE)" 1 -3 December, Hua Hin, Thailand pp. 238-243.

Zhang, T., Liu L., Song Z., Ren G., Feng Y., Han X., Yang G. 2013. Biogas production by co-digestion of goat manure with three crop residues. PLoS ONE 8(6): e66845. DOI:10.1371/journal.pone.0066845. 